\title{
Induction of flowering and improvement of fruit yield and quality in pomegranate (Punica granatum) cv. Bhagwa by various plant growth regulators
}

\author{
Hussain F. ${ }^{1}$, Murthy, B.N.S. ${ }^{2}$, Reddy, M.L.N. ${ }^{3}$, Satisha, $\mathbf{J}^{1}$., Upreti, K.K. ${ }^{4}$, \\ Laxman, R.H. ${ }^{4}$, Srinivasulu, $\mathrm{B}^{3}$
}

\begin{abstract}
The effect of different plant growth regulators on flowering, fruiting, yield, and quality of pomegranate (Punica granatum L.) cv. Bhagwa was studied in a field trial at ICAR - Indian Institute of Horticultural Research (IIHR), Bengaluru, during two seasons, namely ambe bahar (January-February) 2016 and hastha bahar (September-October) 2016-17. Nitrobenzene

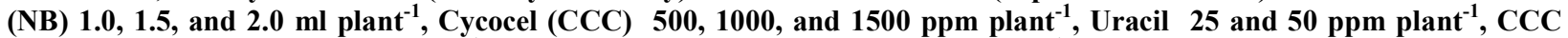

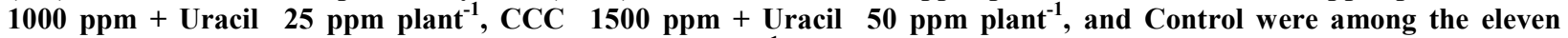
treatments studied. The application of uracil $50 \mathrm{ppm}^{-1 a n t^{-1}}$ resulted in a higher number of hermaphrodite flowers plant $^{-}$ ${ }^{1}$ (264.7), number of fruits plant ${ }^{-1}(154.0)$, and fruit yield $(27.1 \mathrm{~kg} /$ plant). Fruit weight $(197.6 \mathrm{~g})$, fruit length $(6.64 \mathrm{~cm})$, total aril weight $(113.63 \mathrm{~g}), 100$ aril weight $(27.18 \mathrm{~g})$, fruit juice weight (101.94 $\mathrm{g})$, TSS content (19.96 OB), fruit anthocyanin content $(6.46 \mathrm{mg} 100 \mathrm{~g})$ and low titrable acidity $(0.41$ percent) were recorded when CCC $1000 \mathrm{ppm}+\mathrm{Uracil}$ $25 \mathrm{ppm}$ plant $^{-1}$ was applied. During ambe bahar, the highest fruit width $(6.90 \mathrm{~cm})$ and volume $(162.7 \mathrm{ml})$ were observed

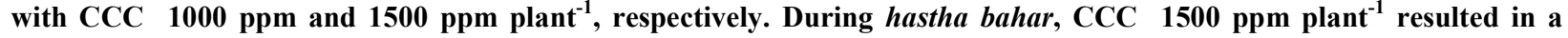
higher number of hermaphrodite flowers $(\mathbf{2 8 7 . 8})$, the highest percentage of fruit set $(\mathbf{8 6 . 1 0})$, the highest number of fruits plant $^{-1}(156.66)$, the highest fruit yield $\left(54.53 \mathrm{~kg} \mathrm{plant}^{-1}\right)$, the highest fruit weight $(348.32 \mathrm{~g})$, the longest fruit length $(8.53$ $\mathrm{cm})$, and the largest fruit volume $(8.53 \mathrm{~cm})(33.93 \mathrm{ml})$, total aril weight $(224.01 \mathrm{~g})$, 100 aril weight $(35.09 \mathrm{~g})$, fruit juice weight $(119.40 \mathrm{~g})$ and TSS content $\left(16.00{ }^{\circ} \mathrm{B}\right)$. A foliar spray of nitrobenzene $1.5 \mathrm{ml} \mathrm{plant}^{-1}$ compounded the high fruit

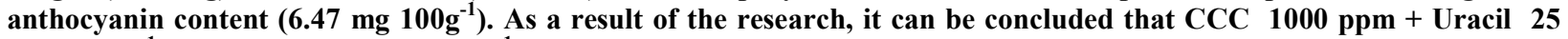
ppm plant ${ }^{-1}$ and $\mathrm{CCC} 1500 \mathrm{ppm}^{-1 a n t^{-1}}$ were the most effective treatments for improving floral characters, fruiting, yield, and quality in pomegranate cv. Bhagwa during both seasons.
\end{abstract}

Key words: Bhagwa, Plant growth Regulators, Pomegranate, Flowering, Yield

\section{Introduction}

Pomegranate (Punica granatum L.) is a nutritious and medicinal hardy fruit crop that can be grown in both tropical and subtropical climates (Aziz and Miah, 2009). The plant is native to Iran, and it was first cultivated there around 2000 B.C. (Supe and Saitwal, 2016). Pomegranate cultivation has grown in popularity over the years due to its adaptability to a wide range of agro-climatic conditions, inherent ability to withstand drought, salinity,

\section{Author's Address}

${ }^{1}$ Division of Fruit Crops, ICAR - Indian Institute of Horticultural Research, Bengaluru, India

${ }^{2}$ Mission for Integrated Development of Horticulture, Ministry of Agriculture and Farmers Welfare, New Delhi, India

${ }^{3} \mathrm{Dr}$ YSR Horticultural University, Venkataramannagudem, Andhra Pradesh - 534 101, India

${ }^{4}$ Division of Plant Physiology and Biochemistry, ICAR - Indian Institute of Horticultural Research, Bengaluru, India

E-mail.: fkhanshaik@gmail.com alkalinity, and high temperature stresses, and commercial profitability (high returns with low input costs), secondary metabolites such as anthocyanins, such as delphinidin, cyanidin, and pelargonidin, and polyphenols, such as ellagic acid and punicalgins, known for their potent antioxidant activities; and profound medicinal and therapeutic value due to the presence of numerous secondary metabolites such as anthocyanins, such as delphinidin, cyanidin, and pelargonidin, and secondary metabolites such as (Pal et al., 2014). India is the world's largest pomegranate producer, with 2.86 million tonnes of fruit produced from 0.24 million hectares of land (National Horticulture Board, 2018). Because of its attractive red skin, deep red arils, soft seeds (mellowness), and export demand, cv. 'Bhagwa' is the most common pomegranate cultivar among the many available 


\section{Hussain et al.}

(Dhinesh et al., 2017). Although the fruit grows exclusively from hermaphrodite flowers, the pomegranate produces three types of flowers: male (bell shaped), hermaphrodite (vase shaped), and intermediate (tubular) (Prasad et al., 2012). If fruit set occurs in such flowers, the fruits can drop off before reaching maturity, even if they become misshaped (Arvind et al., 2018). The percentage of hermaphrodite flowers is proportional to the plant's bearing ability and determines the degree of fruit set (Chaudhari and Desai, 1993). According to studies, cultivars with a high ratio of hermaphrodite to male flowers have a high fruit yield potential, so encouraging the growth of hermaphrodite flowers is an obvious way to increase pomegranate yields (Wetzstein et al., 2015). The male flower's ovary is rudimentary, while the intermediate flower's ovary is degenerating. The ovary of the bisexual flowers is well formed and has a large base. Male flowers drop and do not set, so bisexual flowers are the only ones that produce fruit (Yahya et al., 2017). The climate influences pomegranate flowering, and the plant has three distinct flowering seasons in India (January-February, locally known as ambebahar, June-July, locally known as mrig bahar, and September-October, locally known as hastha bahar (Kumar et al., 2008). The availability of irrigation water, the occurrence and extent of disease and pest damage, and consumer demand all influence the choice of a particular season, or 'bahar,' at a given location (Hoda and Hoda 2013). In temperate and subtropical climates, pomegranate grows as a deciduous shrub, but in India's tropical climate, the plant prefers to remain evergreen and flowers almost all year. As a result of this plant growth pattern, the yield is low and the fruits are of varying sizes (Aziz et al., 2012). Regulating pomegranate flowering in tropical conditions to obtain higher proportions of hermaphrodite flowers would be useful for obtaining higher yields and economic returns (Aseri et al., 2008). Plant growth regulators (PGRs) are said to influence physiological processes and endogenous hormone levels in horticultural crops, resulting in quantitative and qualitative improvements (Phawa et al., 2017). Durgude et al., (2019) found that foliar spray of cycocel $2000 \mathrm{ppm}$ enhanced the number of hermaphrodite flowers in pomegranate cv. Phule Bhagwa. Sangeetha et al., (2014) exonerated that application of $0.5 \%$ nitrobenzene as foliar spray has increased flowering and yield in Moringa. Application of paclobutrazol @ $1.25 \mathrm{~g}$ a.i. per metre canopy diameter induced early flowering in mango cv. Totapuri (Upreti et al., 2012). Many experiments on the use of PGRs in a variety of crops have been attempted. They are considered to play an important role in pomegranate flower sex change (Singh et al., 2016). Auxins, gibberellins, and other growth regulators influence the growth, flowering, yield, and quality of a variety of crops (Aziz et al., 2013). Despite their well-known influence on other fruit crops (Anawal et al., 2015), the effect of PGRs, specifically nitrobenzene, cycocel, and uracil, on flowering, fruit yield, and fruit quality in pomegranate has yet to be investigated - a gap that the current study seeks to fill. In terms of chemical costs, nitrobenzene is the least expensive, followed by cycocel and uracil (Kohombange et al., 2017). There are no studies indicating that nitrobenzene, cycocel, or uracil have a negative impact on human health.

\section{Materials and Methods}

The trial was carried out at the ICAR - IIHR, Hesaraghatta, Bengaluru on safe and uniformly grown tissue - cultured plants of pomegranate cv. Bhagwa obtained from M/s Jain Irrigation Pvt. Ltd, Jalgoan (Maharashtra) during ambe bahar (January - February) and hastha bahar (September October) seasons of 2016-17. During the experiment, the average maximum and minimum temperatures were $33.08^{\circ} \mathrm{C}$ and $20.43^{\circ} \mathrm{C}$, respectively with relative humidity and rainfall of $75.04 \%$ and $74.95 \mathrm{~mm}$. All the plants were initially stressed by withholding irrigation for a month and defoliation was achieved by foliar application of ethrel@2 ml litre (prior to imposition of treatments) followed by twig pruning. The spacing adopted was $4.5 \times 5.0 \mathrm{~m}$. The experiment consisted of eleven treatments that were replicated thrice with a randomized block design. The treatments were: $\mathrm{T}_{1}$ - nitrobenzene $1.0 \mathrm{ml} /$ litre, $\mathrm{T}_{2}-$ nitrobenzene $1.5 \mathrm{ml} /$ litre, $\mathrm{T}_{3}$ - nitrobenzene $2.0 \mathrm{ml} /$ litre, $\mathrm{T}_{4}-$ cycocel $500 \mathrm{ppm}, \mathrm{T}_{5}$ - cycocel $1000 \mathrm{ppm}, \mathrm{T}_{6}-$ cycocel $1500 \mathrm{ppm}, \mathrm{T}_{7}-$ uracil $25 \mathrm{ppm}, \mathrm{T}_{8}$ - uracil $50 \mathrm{ppm}, \mathrm{T}_{9}-$ cycocel $1000 \mathrm{ppm}+$ uracil $25 \mathrm{ppm}$, $\mathrm{T}_{10}$ - cycocel $1500 \mathrm{ppm}+$ uracil $50 \mathrm{ppm}$ and $\mathrm{T}_{11}-$ control (water spray). Before and during the study, 
standard cultural procedures such as desuckering were carried out.

The following observations were recorded: number of flowers of different types, fruit size and yield, and fruit quality parameters. The numbers of male, hermaphrodite, and intermediate flowers were counted from one quarter of the plant canopy of each selected plant and the number per plant was arrived at by multiplying the numbers with four. Fruit set was determined by counting the number of lemon-sized fruits present on the entire plant. Weight of individual fruits was the average weight in grams of nine randomly selected fruits from each treatment. The percentage fruit set was calculated as follows:

\section{$\frac{\text { Number of fruits harvested }}{\text { number of hermaphrodite flowers }} x 100$}

At harvest, the number of fruits from all the treatments was counted and the mean value expressed as the number of fruits per tree. Fruit yield was recorded by recording the weight of fruits harvested at maturity and expressed in kilograms per tree. The length of a fruit was measured from the stalk end to the stylar end using a digital vernier calliper and expressed in centimetres. The maximum width of a fruit was also measured similarly. The volume of nine randomly selected fruits was measured by the water displacement method. Total aril weight was calculated by separating the arils from the randomly selected fruits and weighing them individually, and the mean aril weight was expressed in grams per fruit. The weight of 100 arils was recorded by extracting 100 arils from each of the nine randomly selected fruits from each treatment and the mean value was expressed in grams. Total soluble solids (TSS) were quantified using a hand-held refractometer (Carl Zeiss, Make: Nr 322577, Germany), and the mean value was expressed in ${ }^{\mathrm{O}} \mathrm{Brix}$. Acidity of the juice was estimated by titration (AOAC, 2000). Anthocyanin content of arils was determined by the method described by Srivastava and Kumar (2003): anthocyanin was extracted by putting the samples (10 g each) along with $10 \mathrm{~mL}$ of ethanolic $\mathrm{HCl}$ in a blender, transferring the homogenized suspension to $100 \mathrm{~mL}$ volumetric flasks, making up the volume with ethanolic $\mathrm{HCl}$, storing the mix in a refrigerator at $4{ }^{\circ} \mathrm{C}$, and then filtering through a Whatman No.1 filter paper. The absorbance of the filtrate was recorded at $520 \mathrm{~nm}$.

$$
\text { Anthocyanin }\left(\mathrm{mg} \mathrm{100g}^{-1}\right)=\frac{\text { O.D. }_{\text {.520 }} \times \text { volume made up }}{\text { weight of sample }} X 100
$$

The data were analysed using the analysis of variance (ANOVA; Gomez and Gomez, 1984).

\section{Results and Discussion \\ Effect on flowering}

Data on the effect of various PGRs on flowering are given in Table 1. During Ambe bahar, uracil 50 ppm led to the maximum number of hermaphrodite flowers (264.7); During hastha bahar, it was Cycocel $1500 \mathrm{ppm}$ that achieved a similar result (287.84). The effect of uracil can be attributed to the increase in RNA content (Ramteke and Somkumar, 2005): uracil is a component of RNA, which plays a role in protein synthesis and gene expression and, in turn, in phytohormone production (Sivaningappa et al., 2017). It is evident that exposure of plants to stress in pomegranate promoted accumulation of proline which acted as an endogenous signal to induce flowering (Neale, 1990). Further, a positive correlation was observed between leaf proline content and the number of hermaphrodite flowers produced (Powerwanto and Inoue, 1990). Application of ethrel at high concentration ( $2 \mathrm{ml} /$ litre) to defoliate pomegranate also regulates flowering (Saroj et al., 2017). Foliar application of ethrel causes activated gene expression of cell-wall degrading enzymes such as cellulase and polygalacturonase. Ethrel perception was found involved in the arrest of stamen development through induction of DNA damage which promotes hermaphrodite flower production in some plant species (Xie et al., 2015). The effect of Cycocel can be attributed to lower levels of endogenous gibberellins, which inhibit the conversion of geranylgeranyl pyrophosphate to entkaurene in the gibberellin synthesis pathway (Jain and Dashora, 2007). Reduced gibberellin inhibits cell elongation, reducing annual vegetative growth and promoting reproductive growth, as evidenced by the increased number of hermaphrodite flowers. Hezagi and Stino (1985) found a higher proportion of hermaphrodite flowers in olive with application of cycocel. 
Hussain et al.

Table 1: Induction of flowering in pomegranate as influenced by different plant growth regulators

\begin{tabular}{|c|c|c|c|c|c|c|}
\hline \multirow[b]{2}{*}{ Treatment } & \multicolumn{3}{|c|}{ Ambe bahar (Jan.-Feb. 2016) } & \multicolumn{3}{|c|}{ Hastha bahar (Sept.-Oct. 2016) } \\
\hline & $\begin{array}{l}\text { Number } \\
\text { of male } \\
\text { flowers }\end{array}$ & $\begin{array}{l}\text { Number of } \\
\text { hermaphrodite } \\
\text { flowers }\end{array}$ & $\begin{array}{l}\text { Number of } \\
\text { intermediate } \\
\text { flowers }\end{array}$ & $\begin{array}{l}\text { Number } \\
\text { of male } \\
\text { flowers }\end{array}$ & $\begin{array}{l}\text { Number of } \\
\text { hermaphrodite } \\
\text { flowers }\end{array}$ & $\begin{array}{l}\text { Number of } \\
\text { intermediate } \\
\text { flowers }\end{array}$ \\
\hline $\begin{array}{l}\mathrm{T}_{1}, \text { nitrobenzene } \\
1.0 \mathrm{~mL} / \text { plant }\end{array}$ & 264.66 & 215.66 & 179.66 & 277.40 & 195.05 & 215.43 \\
\hline $\begin{array}{l}\mathrm{T}_{2}, \text { nitrobenzene } \\
1.5 \mathrm{~mL} / \text { plant }\end{array}$ & 274.00 & 206.66 & 201.83 & 283.42 & 203.66 & 231.23 \\
\hline $\begin{array}{l}\mathrm{T}_{3}, \text { nitrobenzene } \\
2.0 \mathrm{~mL} / \text { plant }\end{array}$ & 268.66 & 211.66 & 198.66 & 252.27 & 241.02 & 234.57 \\
\hline $\begin{array}{l}\mathrm{T}_{4},(\text { Cycocel }) \\
500 \mathrm{ppm}\end{array}$ & 288.33 & 193.33 & 197.16 & 243.79 & 256.69 & 238.52 \\
\hline $\begin{array}{l}\mathrm{T}_{5}, \quad(\text { Cycocel }) \\
1000 \mathrm{ppm}\end{array}$ & 277.83 & 196.66 & 195.66 & 232.63 & 261.19 & 245.02 \\
\hline $\begin{array}{l}\mathrm{T}_{6}, \quad(\text { Cycocel }) \\
1500 \mathrm{ppm}\end{array}$ & 258.00 & 190.66 & 196.66 & 219.70 & 287.84 & 250.53 \\
\hline $\begin{array}{l}\mathrm{T}_{7}, \text { uracil } \\
25 \mathrm{ppm}\end{array}$ & 258.00 & 259.66 & 195.66 & 252.13 & 220.73 & 230.50 \\
\hline $\begin{array}{l}\mathrm{T}_{8}, \text { uracil } \\
50 \mathrm{ppm}\end{array}$ & 241.00 & 264.66 & 194.33 & 241.69 & 222.66 & 236.40 \\
\hline $\mathrm{T}_{9}, \mathrm{~T} 5+\mathrm{T} 7$ & 275.33 & 201.33 & 207.83 & 234.75 & 239.99 & 250.08 \\
\hline $\mathrm{T}_{10}, \mathrm{~T} 6+\mathrm{T} 8$ & 287.66 & 196.00 & 226.66 & 234.99 & 243.43 & 254.14 \\
\hline $\mathrm{T}_{11}$, Control & 312.33 & 188.66 & 190.00 & 286.14 & 181.85 & 204.06 \\
\hline C.D. at $5 \%$ & N.S. & 44.10 & N.S. & 14.68 & 11.51 & 11.22 \\
\hline S. Em $( \pm)$ & 16.74 & 14.84 & 12.27 & 4.94 & 3.87 & 3.77 \\
\hline
\end{tabular}

* N.S. - Non Significant

Effect on yield and its attributes

The percentage of fruit set in the ambe bahar was unaffected by any of the treatments (Table 2), while uracil $50 \mathrm{ppm}$ increased the number of fruits to 154 and the fruit yield to $27.1 \mathrm{~kg}$ per plant. Cycocel $1500 \mathrm{ppm}$ increased fruit set $(86.1 \%)$, number of fruits per plant (156.7), and maximum yield (54.5 $\mathrm{kg}$ per plant) in the hastha bahar, outperforming all of the other nine treatments. The increased number of hermaphrodite flowers and delayed abscission (the effect of cytokinins and auxins) achieved by retaining the pectin content in the middle lamella (Kachave and Bhosale, 2007), effect on sex expression (Chaudhari and Desai, 1993), and better pollen tube growth leading to reduced flower drop could all contribute to Cycocel's improved fruit

collection. Increased amounts of metabolites are required for fruit growth as a result of restricted vegetative growth. Similar findings were made in mango (Daulta et al., 1981) and guava (Daulta et al., 1981). (Saravanan and Kanowjia, 2008). The increased number of hermaphrodite flowers resulted in increased fruit set and retention, as well as an increase in the number of fruits per plant. These findings are similar to those of Desai et al. (1982) in 'Kagzi' lime and Guha (1993) in apple. Cycocel, a growth retardant, is said to change the source-sink relationship in plants by redeploying carbohydrates directly or indirectly to suppress vegetative growth and encourage reproductive growth, resulting in increased yield. Furthermore, 
Cycocel and uracil influence auxin metabolism, (1972) reported similar results in mango, and which may have resulted in increased fruit number Shawky et al., (1998) and Shikhamany and Reddy and size, resulting in increased yield. Maiti et al., (1989) reported similar results in grapes.

Table 2: Fruit yield and its attributes in pomegranate as influenced by different plant growth regulators

\begin{tabular}{|c|c|c|c|c|c|c|}
\hline \multirow[b]{2}{*}{ Treatment } & \multicolumn{3}{|c|}{ Ambe bahar (Jan.-Feb. 2016) } & \multicolumn{3}{|c|}{ Hastha bahar (Sept.-Oct. 2016) } \\
\hline & Fruit set $(\%)$ & $\begin{array}{l}\text { Number of } \\
\text { Fruits/plant }\end{array}$ & $\begin{array}{l}\text { Fruit Yield } \\
\text { (kg/plant) }\end{array}$ & $\begin{array}{l}\text { Fruit } \\
\text { set }(\%)\end{array}$ & $\begin{array}{l}\text { Number of } \\
\text { Fruits/plant }\end{array}$ & $\begin{array}{l}\text { Fruit yield } \\
\text { (kg/tree) }\end{array}$ \\
\hline $\begin{array}{l}\mathrm{T}_{1} \text {, nitrobenzene } \\
1.0 \mathrm{~mL} / \text { plant }\end{array}$ & 66.30 & 139.16 & 24.73 & 37.52 & 96.33 & 26.66 \\
\hline $\begin{array}{l}\mathrm{T}_{2}, \text { nitrobenzene } \\
1.5 \mathrm{~mL} / \text { plant }\end{array}$ & 55.76 & 113.83 & 21.50 & 40.63 & 106.00 & 29.68 \\
\hline $\begin{array}{l}\mathrm{T}_{3}, \text { nitrobenzene } \\
2.0 \mathrm{~mL} / \text { plant }\end{array}$ & 62.77 & 132.00 & 24.18 & 48.01 & 115.66 & 32.52 \\
\hline $\mathrm{T}_{4},($ Cycocel) $500 \mathrm{ppm}$ & 51.67 & 99.66 & 19.61 & 70.01 & 142.66 & 45.12 \\
\hline $\mathrm{T}_{5},($ Cycocel) $1000 \mathrm{ppm}$ & 54.22 & 105.00 & 20.36 & 75.50 & 147.33 & 47.93 \\
\hline $\mathrm{T}_{6},($ Cycocel $) 1500 \mathrm{ppm}$ & 52.01 & 99.16 & 18.70 & 86.10 & 156.66 & 54.53 \\
\hline $\mathrm{T}_{7}$, uracil $25 \mathrm{ppm}$ & 59.09 & 153.00 & 26.98 & 39.26 & 94.33 & 28.38 \\
\hline $\mathrm{T}_{8}$, uracil $50 \mathrm{ppm}$ & 58.16 & 154.00 & 27.10 & 40.36 & 98.33 & 29.90 \\
\hline $\mathrm{T}_{9}, \mathrm{~T} 5+\mathrm{T} 7$ & 55.55 & 107.00 & 20.98 & 46.72 & 104.00 & 29.21 \\
\hline $\mathrm{T}_{10}, \mathrm{~T} 6+\mathrm{T} 8$ & 56.08 & 106.00 & 19.84 & 51.02 & 112.66 & 32.80 \\
\hline $\mathrm{T}_{11}$, Control & 52.05 & 98.33 & 16.31 & 31.49 & 90.66 & 24.52 \\
\hline C.D. at $5 \%$ & N.S. & 31.90 & 6.39 & 4.18 & 12.42 & 5.78 \\
\hline S.Em $( \pm)$ & 7.00 & 10.73 & 2.15 & 1.41 & 4.18 & 1.94 \\
\hline
\end{tabular}

* N.S. - Non Significant

Table 3: Fruit size in pomegranate as influenced by different plant growth regulators

\begin{tabular}{|c|c|c|c|c|c|c|c|c|}
\hline \multirow{2}{*}{ Treatment } & \multicolumn{4}{|c|}{ Ambe bahar (Jan.-Feb. 2016) } & \multicolumn{4}{|c|}{ Hastha bahar (Sept.-Oct. 2016) } \\
\hline & $\begin{array}{l}\text { Weight } \\
\text { (g) }\end{array}$ & $\begin{array}{l}\text { Length } \\
(\mathrm{cm})\end{array}$ & $\begin{array}{l}\text { Fruit } \\
\text { Width (cm) }\end{array}$ & $\begin{array}{l}\text { Volume } \\
(\mathrm{mL})\end{array}$ & $\begin{array}{l}\text { Weight } \\
\text { (g) }\end{array}$ & $\begin{array}{l}\text { Length } \\
(\mathrm{cm})\end{array}$ & $\begin{array}{l}\text { Width } \\
\text { (cm) }\end{array}$ & $\begin{array}{l}\text { Volume } \\
(\mathrm{mL})\end{array}$ \\
\hline $\begin{array}{l}\mathrm{T}_{1} \text {, nitrobenzene } 1.0 \\
\mathrm{~mL} / \text { plant }\end{array}$ & 177.80 & 6.34 & 6.49 & 136.58 & 276.61 & 7.65 & 7.83 & 267.37 \\
\hline $\begin{array}{l}\mathrm{T}_{2}, \text { nitrobenzene } 1.5 \\
\mathrm{~mL} / \text { plant }\end{array}$ & 187.07 & 6.47 & 6.74 & 125.53 & 280.13 & 7.82 & 7.98 & 276.86 \\
\hline $\begin{array}{l}\mathrm{T}_{3}, \text { nitrobenzene } 2.0 \\
\mathrm{~mL} / \text { plant }\end{array}$ & 183.00 & 6.18 & 6.38 & 143.26 & 281.24 & 7.86 & 8.06 & 267.17 \\
\hline $\begin{array}{ll}T_{4}, \quad(C y c o c e l) & 500 \\
\text { ppm }\end{array}$ & 196.31 & 6.57 & 6.83 & 160.08 & 315.86 & 8.33 & 8.28 & 300.60 \\
\hline $\begin{array}{ll}\mathrm{T}_{5}, & (\text { Cycocel }) 1000 \\
\mathrm{ppm}\end{array}$ & 193.66 & 6.57 & 6.84 & 162.70 & 325.05 & 8.49 & 8.36 & 310.60 \\
\hline $\begin{array}{l}\mathrm{T}_{6},(\text { Cycocel }) 1500 \\
\mathrm{ppm}\end{array}$ & 187.25 & 6.50 & 6.90 & 155.62 & 348.32 & 8.53 & 8.96 & 333.93 \\
\hline $\mathrm{T}_{7}$, uracil $25 \mathrm{ppm}$ & 176.82 & 6.40 & 6.67 & 126.43 & 299.93 & 8.04 & 8.12 & 263.80 \\
\hline $\mathrm{T}_{8}$, uracil $50 \mathrm{ppm}$ & 176.88 & 6.37 & 6.75 & 125.37 & 303.91 & 8.11 & 7.96 & 287.06 \\
\hline $\mathrm{T}_{9}, \mathrm{~T} 5+\mathrm{T} 7$ & 197.55 & 6.64 & 6.82 & 160.54 & 280.82 & 8.34 & 8.06 & 239.41 \\
\hline $\mathrm{T}_{10}, \mathrm{~T} 6+\mathrm{T} 8$ & 187.43 & 6.62 & 6.59 & 150.60 & 290.75 & 8.00 & 8.14 & 203.87 \\
\hline $\mathrm{T}_{11}$, Control & 166.54 & 6.03 & 6.20 & 135.05 & 270.41 & 7.71 & 7.66 & 263.74 \\
\hline C.D. at $5 \%$ & 15.66 & 0.39 & 0.30 & 27.81 & 23.62 & 0.58 & N.S. & 37.53 \\
\hline S.Em $( \pm)$ & 5.27 & 0.13 & 0.10 & 9.36 & 7.95 & 0.19 & 0.35 & 12.63 \\
\hline
\end{tabular}

* N.S. - Non Significant 
Hussain et al.

Table 4: Fruit quality parameters in pomegranate as influenced by different plant growth regulators

\begin{tabular}{|c|c|c|c|c|c|c|c|c|c|c|c|c|}
\hline \multirow[b]{2}{*}{ Treatment } & \multicolumn{6}{|c|}{ Ambe bahar (Jan.-Feb. 2016) } & \multicolumn{6}{|c|}{ Hastha bahar (Sept.-Oct. 2016) } \\
\hline & $\begin{array}{l}\text { Total aril } \\
\text { weight }(\mathrm{g})\end{array}$ & $\begin{array}{l}\text { 100-aril } \\
\text { weight } \\
\text { (g) }\end{array}$ & $\begin{array}{l}\text { Juice } \\
\text { weight } \\
\text { (g) }\end{array}$ & $\begin{array}{l}\text { TSS } \\
\left({ }^{\circ} \mathbf{B}\right)\end{array}$ & $\begin{array}{l}\text { Titrable } \\
\text { acidity } \\
(\%)\end{array}$ & $\begin{array}{l}\text { Anthocyanin } \\
\left(\mathrm{mg} 100 \mathrm{~g}^{-1}\right)\end{array}$ & $\begin{array}{l}\text { Total aril } \\
\text { weight (g) }\end{array}$ & $\begin{array}{l}100 \quad \text { Aril } \\
\text { weight }(g)\end{array}$ & $\begin{array}{l}\text { Juice } \\
\text { weight } \\
\text { (g) }\end{array}$ & $\begin{array}{l}\text { TSS } \\
\left({ }^{\circ} \mathbf{B}\right)\end{array}$ & $\begin{array}{l}\text { Titrable } \\
\text { acidity } \\
(\%)\end{array}$ & $\begin{array}{l}\text { Anthocyanin } \\
\left({\left.\mathrm{mg} 100 \mathrm{~g}^{-1}\right)}^{-1}\right.\end{array}$ \\
\hline $\begin{array}{l}\mathrm{T}_{1} \text {, nitrobenzene } 1.0 \\
\mathrm{~mL} / \text { plant }\end{array}$ & 95.73 & 24.92 & 56.91 & 18.50 & 0.54 & 5.07 & 149.21 & 32.15 & 92.01 & 15.76 & 0.63 & 5.08 \\
\hline $\begin{array}{l}\mathrm{T}_{2}, \text { nitrobenzene } 1.5 \\
\mathrm{~mL} / \text { plant }\end{array}$ & 103.94 & 24.42 & 89.93 & 16.39 & 0.68 & 5.14 & 160.01 & 28.96 & 93.90 & 15.94 & 0.57 & 6.47 \\
\hline $\begin{array}{l}\mathrm{T}_{3}, \quad \text { nitrobenzene } 2.0 \\
\mathrm{~mL} / \text { plant }\end{array}$ & 97.30 & 24.65 & 62.01 & 18.25 & 0.52 & 5.27 & 159.72 & 31.02 & 96.70 & 15.44 & 0.52 & 5.27 \\
\hline $\mathrm{T}_{4},($ Cycocel) $500 \mathrm{ppm}$ & 110.80 & 26.97 & 92.31 & 19.12 & 0.48 & 5.60 & 191.98 & 32.25 & 112.38 & 15.15 & 0.58 & 5.61 \\
\hline $\begin{array}{ll}\mathrm{T}_{5}, & \text { (Cycocel) } 1000 \\
\mathrm{ppm} & \\
\end{array}$ & 105.00 & 26.58 & 86.66 & 19.44 & 0.43 & 5.80 & 199.98 & 34.24 & 115.87 & 14.45 & 0.68 & 5.81 \\
\hline 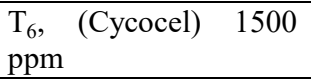 & 104.84 & 25.87 & 72.37 & 19.96 & 0.41 & 5.11 & 224.01 & 35.09 & 119.40 & 16.00 & 0.54 & 5.11 \\
\hline $\mathrm{T}_{7}$, uracil $25 \mathrm{ppm}$ & 96.26 & 23.86 & 60.73 & 15.82 & 0.66 & 4.66 & 177.77 & 31.89 & 95.57 & 14.70 & 0.64 & 4.66 \\
\hline $\mathrm{T}_{8}$, uracil $50 \mathrm{ppm}$ & 98.55 & 24.74 & 51.27 & 17.22 & 0.67 & 4.84 & 188.07 & 28.28 & 94.16 & 14.38 & 0.68 & 4.85 \\
\hline $\mathrm{T}_{9}, \mathrm{~T} 5+\mathrm{T} 7$ & 113.63 & 27.18 & 101.94 & 16.07 & 0.69 & 6.46 & 168.85 & 32.52 & 89.06 & 15.60 & 0.55 & 5.15 \\
\hline $\mathrm{T}_{10}, \mathrm{~T} 6+\mathrm{T} 8$ & 97.05 & 24.50 & 88.95 & 16.16 & 0.70 & 4.81 & 177.79 & 30.86 & 91.39 & 15.52 & 0.70 & 4.81 \\
\hline $\mathrm{T}_{11}$, Control & 84.13 & 20.07 & 61.10 & 15.46 & 0.60 & 3.55 & 128.37 & 27.64 & 86.95 & 14.00 & 0.75 & 3.57 \\
\hline C.D. at $5 \%$ & 14.63 & 2.78 & 25.87 & 1.54 & 0.17 & 1.23 & 27.86 & 2.82 & 15.57 & 1.16 & N.S. & 1.23 \\
\hline $\operatorname{S.Em}( \pm)$ & 4.92 & 0.93 & 8.71 & 0.51 & 0.05 & 0.41 & 9.37 & 0.95 & 5.24 & 0.39 & 0.08 & 0.41 \\
\hline
\end{tabular}

* N.S. - Non Significant 


\section{Fruit size}

In both seasons, the PGRs had a major impact on all of the fruit's characteristics (Table 3). In the ambe bahar, Cycocel $1000 \mathrm{ppm}$ in combination with uracil $25 \mathrm{ppm}$ produced large fruits with a weight of $197.6 \mathrm{~g}$ and a length of $6.6 \mathrm{~cm}$, Cycocel 1500 with a width of $6.9 \mathrm{~cm}$, and Cycocel 1000 ppm with a large volume $(162.7 \mathrm{~mL})$. The highest values of all four measurements were obtained with Cycocel 1500 in the hastha bahar. The larger fruit size obtained with Cycocel (on all four scales, namely weight, length, width, and volume) was due to photosynthates being guided to developing fruits as a result of Cycocel's suppression of vegetative growth by blocking gibberellin synthesis. The same results were observed in olive cv. 'Pendulino' by Arun et al. (2016). The increase in fruit volume was a clear product of the increase in length and width, which was most likely caused by increased levels of endogenous auxins, which promote cell elongation. These findings are similar to those made by Kurian and Iyer (1992) in the mango cv. 'Alphonso' and Pandey et al. (2001) in the guava.

\section{Fruit quality}

The PGRs had a big impact on the fruit production (Table 4). Cycocel $1000 \mathrm{ppm}$ in combination with uracil $25 \mathrm{ppm}$ produced the highest total aril weight (113.6 g), 100-aril weight (27.18 g), and maximum juice $(101.94 \mathrm{~g})$, as well as the highest anthocyanin content $(6.46 \mathrm{mg} 100 \mathrm{~g})$ in the ambe bahar, while Cycocel $1500 \mathrm{ppm}$ alone produced the sweetest (high TSS of $19.96^{\circ} \mathrm{B}$ ) and least acidic juice fruits (0.41 percent). On all counts, Cycocel 1500 ppm was the best in the hastha bahar. It resulted in higher total aril weight, 100-aril weight, TSS, and least acidity, with the exception of colour, where plants treated with nitrobenzene $1.5 \mathrm{~mL} / \mathrm{L}$ per plant had the highest anthocyanin content. The larger fruits, as a result of a better physiological response in terms of the supply of water, nutrients, and other metabolites necessary for proper growth and development, resulted in heavier arils following the application of Cycocel. Varasteh et al., (2008) made similar observations in pomegranate. The increase in 100-aril weight may be due to larger cells and intercellular spaces - a Cycocel effect combined with increased deposition of water, sugars, and other soluble solids as a result of metabolite translocation into the fruit. Anawal et al., (2015) found similar results in the pomegranate cv. 'Bhagwa'. Apart from heavier arils, the increase in juice quantity was most likely due to larger and heavier fruits, as stated by Bankar and Prasad in pomegranate cv. 'Ganesh' (1992). The translocation of sugars and water to the arils tends to be the cause of the rise in juice volume. The proportion of seeds may have decreased in proportion to the increase in the amount of juice as the water content of arils increased. Supe and Saitwal (2016) found similar findings in pomegranate cv. 'Mridula.' The higher Brix reading after using Cycocel was most likely due to increased metabolism, as shown by higher osmotic pressure in cells, which appears to increase the accumulation of solutes including ions and sugars (Singh, 2016). Another explanation may be that Cycocel-treated plants have a more effective photosynthetic apparatus (leaves), resulting in higher TSS content, as Bikramjit et al., (2012) found in pomegranate. The rise in total anthocyanins after the use of nitrobenzene and Cycocel was most likely due to the continued synthesis of phenolic compounds after harvest to keep the ripening process going. The activity of enzymes involved in the anthocyanin synthesis pathway, such as phenylalanine ammonia lyase (PAL) and UDP-glucose, flavonoid-3-0-glucosyl transferase, may also play a role in the increase in anthocyanin concentration after harvest (GT). Gil et al., (1995) also obtained similar findings in grape.

\section{Conclusion}

Foliar spray showed that uracil $50 \mathrm{ppm}$ in the ambe bahar led to production of higher number of hermaphrodite flowers (264.7) and fruits (154.0) and yield $(27.1 \mathrm{~kg})$ per plant whereas Cycocel at $1000 \mathrm{ppm}$ in combination with uracil at $25 \mathrm{ppm}$ led to increased fruit size (197.6 g), juice content $(102 \mathrm{~g})$, TSS $\left(19.96{ }^{\circ} \mathrm{B}\right)$, and aril colouration (anthocyanin content $6.46 \mathrm{mg} 100 \mathrm{~g}^{-1}$ ). In the hastha bahar, Cycocel at $1500 \mathrm{ppm}$ proved superior on almost every count (number of hermaphrodite flowers, percentage of fruit set and number of fruits per plant. Therefore, a foliar spray of Cycocel $1000 \mathrm{ppm}$ and uracil $25 \mathrm{ppm}$ combination in winter or Cycocel $1500 \mathrm{ppm}$, in the hastha bahar, is recommended for fetching high fruit yield and better-quality fruits of pomegranate in India. 
Hussain et al.

\section{Acknowledgements}

The authors would like to thank Dr V.K. Rao, Principal scientist, Division of plant physiology and

\section{References}

Anawal, V.V., Narayana S. P. and Ekabote, S.D. 2015. Effects of plant growth regulators on fruit set and yield of pomegranate cv. Bhagwa. International Journal of Science and Research. 4(9): 220-222.

AOAC. 2000. Official Methods of Analysis, third ed. Association of Official Analytical Chemists, Washington, D.C.

Arun, K, Sharma, N. and Gopal, Singh. 2016. Effect of paclobutrazol and cycocel on growth, flowering and physiological characteristics of olive cv. Pendulino. Plant Archives. 16, 110-114.

Arvind, K., Satya, P. and Jeetendra, K. 2018. Studies on flowering behaviour of pomegranate (Punica granatum L.) with special reference to red aril cultivars. Progressive Agriculture. 18(1): 110-112.

Aseri, G.K., Neelam, J., Jitendra, P., Rao, A.V. and Meghwal, P.R. 2008. Biofertilizers improve plant growth, fruit yield, nutrition, metabolism and rhizosphere enzyme activities of Pomegranate (Punica granatum L.) in Indian Thar Desert. Scientia Horticulturae. 117: 130-135.

Aziz, M.A. and Miah, M.A.M. 2009. Effect of 'Flora' on the Growth and Yield of Wetland Rice. Journal of Agriculture and Rural Development. 7(1\&2): 9-13.

Aziz, R.A.B., Naira, A. and Ashraf, M. 2012. Effect of biostimulants on flowering, fruit drop, yield and return bloom of pomegranate cv. Kandhari Kabuli. The Asian Journal of Horticulture. 7(2): 1473-477.

Aziz, M.A., Miah, M.A.M. and Rahul, K. 2013. Effect of nitrobenzene on flowering, yield and quality in Sunflower. Journal of Agriculture and Rural Development. 8: 125128.

Babu, D.K. 2010. Floral biology of pomegranate (Punica granatum L.). Fruit, Vegetable and Cereal Science and Biotechnology. 4(2), 45-50.

Bankar, G.J., and Prasad, R.N. 1992. Performance of important pomegranate cultivars in arid region. Annals of Arid Zone. 31: 181-183.

Bikramjit S., Sukhdev, S. and Sandhu, S. 2012. Effect of growth retardants on vegetative growth, flowering and fruiting of Litchi cv. Calcuttia. HortFloraSpectr. 1, 29-33.

Chaudhari, S.M. and Desai, U.T. 1993. Effects of plant growth regulators on flower sex in pomegranate (Punica granatum L.). Indian Journal of Agricultural Sciences. 63: 34-35.
Bio chemistry, ICAR - IIHR, Bengaluru for providing the lab and chemicals.

Daulta, B.S., Singh, H.K. and Chohan, K.S. 1981. Effect of zinc and CCC sprays on flowering, fruiting and physicochemical composition on fruit in mango (Mangiferaindica L.) cv. Dashehari. Haryana Journal of Horticultural Sciences. 10: 161-165.

Desai, U.T., Choudhari, K.G., Ran, S.D. and Patil, Y.S. 1982. Alteration of flowering period in Kagzi lime with plant growth substances. Journal of Maharashtra Agricultural University. 7: 161-162.

Dhinesh, B. K., Singh, N.V., Gaikwad, N, Maity, A, Suryavanshi, S.K. and Pal, R.K. 2017. Determination of maturity indices for harvesting of pomegranate (Punica granatum). Indian Journal of Agricultural Sciences. 87(9): 1225-30.

Durgude, R.A., Supe, V.S., Kulkarni, S.S., Chavan, U.D and Nimbalkar, C.A. 2019. Effect of different chemicals on flowering, fruit set and yield in pomegranate (Punica granatum L.) cv. Bhagwa. International Journal of Chemical Studies. 7(3): 1836-1841.

Gil, M.I., Garcia-Viguera, C., Artes, F. and Tomas-Barberan, F.A. 1995. Changes in pomegranate juice pigmentation during ripening. Journal of Science and Food Agriculture. 68: 77-81.

Gomez, K.A. and Gomez, A.A. 1984. Statistical Procedure for Agricultural Research, second ed. John Wiley, New York. 278

Guha, D. 1993. Regulation of tree growth and yield in Golden Delicious apple with Cycocel and Ethrel. South Indian Journal of Horticulture. 41: 333-340.

Hezagi, E.S. and Stino, G.R. 1985. Chemical regulation of sex expression in certain olive cultivars. Acta Agrobotany. 35: $185-190$

Hoda, Khalil, A. and Hoda, Aly, S.H. 2013. Cracking and Fruit Quality of Pomegranate (Punica granatum L.) as affected by pre harvest sprays of some growth regulators and mineral nutrients. Journal of Horticultural Science and Ornamental Plants. 5(2): 71-76.

Jain, M.C. and Dashora, L.K. 2007. Growth, flowering, fruiting and yield of guava (Psidium guajava L.) cv. Sardar as influenced by various plant growth regulators. International Journal of Agriculture Sciences. 3: 4-7.

Kachave, D.B. and Bhosale, A.M. 2007. Effect of plant growth regulators and micronutrients on fruiting and yield parameters of Kagzi lime (Citrus aurantifolia Swingle) fruits. Asian Journal of Horticulture. 2: 75-79. 
Kohombange, S, Gunasekera, K.H.L.K. and Kirindigoda, S. 2017. Effects of various concentrations of Nitrobenzene on Bell Pepper (Capsicum annum L.). Journal of Horticulture. 4:4.

Kumar, V., Singh, A.R., Singh, G.N. and Pal, S.L. 2008. Correlation between flowering and yield characters in pomegranate (Punica granatum L.). Annals of Horticulture. 1(1): 73-75.

Kurian, R.M. and Iyer, C.P.A. 1992. Stem anatomical characters in relation to the vigour in mango. Scientia Horticulturae. 50: 245-253.

Maiti, S.C., Basu, R.N. and Sen, P.K. 1972. Chemical control of growth and flowering in Mangifera indica L. Acta Horticulture. 24:192-195.

National Horticulture Board, 2018. Area and Production of Horticulture Crops: All India. (accessed 4 March 2020). http://nhb.gov.in/statistics/State_Level/2018-19.(1st\%20Adv).pdf

Neale, A. D, Wahleithner, J. A., Lund, M., Bonnet. H. T., Kelly, A., Meeks - Wagner, D. R., Peacock, W. J. and Dennis, E.S. 1990. Chitinase (3-1, 3-gluconase, osmotin, and extension are expressed in tobacco explants during flower formation. Plant Cell. 2: 673-84.

Pal, R.K., Babu, D.K. Singh, N.V. Maity, A. and Gaikwad, N. 2014. Pomegranate research in India:Status and future challenges. Progressive Horticulture. 46: 184-201.

Pandey, D.K, Goswamy, C.L. and Kumar, R. 2001. Effect of plant growth regulators on photosynthesis under water logging. Indian Journal of Plant Physiology. 6: 90-94.

Pareek, O.P. and Sharma, S. 1993. Genetic resources of under exploited fruits,In: Chadha K.L., Pareek O.P. (Eds). Advances in Horticulture. vol.1. Malhotra Publication,New Delhi,pp. 189-225.

Phawa, T., Prasad, V.M. and Rajwade, V.B. 2017. Effect of plant growth regulators on growth and flowering of pomegranate (Punica granatum L.) cv. Kandhari in Allahabad agro-climatic conditions. International Journal of Current Microbiology and Applied Sciences. 6: 116121.

Powerwanto, R. and Inoue, H. 1990. Effects of air soil temperatures in autumn on flower induction and some physiological responses of Satsuma mandarin. Journal of Japanese Society of Horticultural Sciences. 59(2): 20714.

Prasad, K.R.S., Mukunda, G.K., Mohan, Kumar, A.B. and Yathiraj, K. 2012. Comparative studies in certain commercially important varieties of pomegranate (Vegetative growth, flowering, fruit set and yield). The Asian Journal of Horticulture. 7(2): 521-523.
Ramteke, S.D. and Somkumar, R.G. 2005. Effect of cycocel sprays on growth and yield of Tas-A-Ganesh grapes grafted on dogridgerootstock. Karnataka Journal of Agricultural Sciences. 18: 18-20.

Saroj, P. L, Sharma, B. D. and Kumar, R. 2017. Pomegranate flower regulation and its physiology. $2^{\text {nd }}$ National Seminar - Cum Farmers Fair. Pomegranate for Health, Growth and Prosperity, Pp. 87-94.

Sangeetha, V. and Ponnuswami, V. 2014. Influence of Different Package of Practices, Growth Regulators and Chemical on Flowering and Yield of Moringa (Moringa Oliefera lam.) Varieties. Trends in Biosciences. 7(8): 670674.

Saravanan, S. and Kanowjia, A. 2008. Effect of gibberellic acid on fruit set and physico-chemical properties of guava (Psidium guajava L.). Allahabad Farmer. 64: 72-76.

Shin, Shinde, A.K, Waghmare, G.M, Wagh, R.G. and Burondkar, M.M. 2000. Effect of dose and time of paclobutrazol application on flowering and yield of mango. Indian Journal of Plant Physiology. 5(1): 82-84.

Sivaningappa, K., Patil, D.R., Kishore, K. D., Swamy, G.S.K., Thammaiah, N., Jayappa, J. and Kantesh, G. 2017. Studies on the influence of growth regulators and chemicals on the quality parameters of Grape cv. 2A Clone. International Journal of Current Microbiology and Applied Sciences. 6(5): 2585-2592.

Singh, N.P., Dhillon, W.S., Sharma, K.K. and Dhat, A.S. 2016. Effect of mechanical deblossoming on flowering and fruit set in pomegranate cvs. Ganesh -1 and Kandhari. Indian Journal of Horticulture. 63(4): 383-385.

Singh, D.K. 2016. Effect of paclobutrazol on growth and bearing mango cultivars. Ph.D. thesis submitted to G. B. Pant University of Agriculture and Technology, Pantnagar, Uttar Pradesh, India.

Shawky, I., Zidan, Z. Thomi, A.E. and Dashan, D. 1998. Effect of $\mathrm{GA}_{3}$ sprays on lime of blooming and flowering malformation in Taimour mango. Egyptian Journal of Horticulture. 5: 123-132.

Shikhamany, S.D., and Reddy, N.N. 1989. Effect of growth retardant on growth, yield and quality in grape cv. Thompson Seedless. Indian Journal of Horticulture. 46: $31-37$.

Srivastava, R.P. and Kumar, S. 2003. Fruits and Vegetable Preservation. International Book Distributing Company, Lucknow, India.

Supe, V.S. and Saitwal, Y.S. 2016. Morphological, biochemical and qualitative changes associated with growth and development of pomegranate fruit (Punica granatum L.). Indian Journal of Agricultural Research. 50: $80-83$. 


\section{Hussain et al.}

Upreti, K.K., Reddy, Y.T.N., Shivu, Prasad, S.R., Bindu, G.V., Jayaram, H.L. and Rajan, S. 2012. Hormonal changes in response to paclobutrazol induced early flowering in mango cv. Totapuri. Scientia Horticulturae. 414-418.

Varasteh, F., Arzani, K., Zamani, Z., and Tabatabaei, S.Z. 2008. Physico-chemical seasonal changes of pomegranate (Punica granatum L.) fruit 'Malas-e-Torsh-e-Saveh'in Iran. Acta Horticulturae. 769: 255-258.

Wetzstein, H.Y., Ravid, N. and Wilkins, E. 2015. A morphological and histological characterization of bisexual and male flower types in pomegranate. Journal of American Society of Horticultural Sciences. 136: 83-92.

Xie, S, Lu, Xiaopeng, Zhao, Xiaoli and Nie, Qun. 2015. Effect of water stress on vegetative growth and nitrogen metabolism of pomegranate seedling. Acta Horticulturae. 1089: 63-69.

Yahya, S., Zabihollah, Z., Reza, F and Ali - Reza, T. 2017. Effect of deficit irrigation on flowering and fruit properties of pomegranate (Punica granatum cv. Shahvar). Agricultural Water Management. 192: 189-197. 